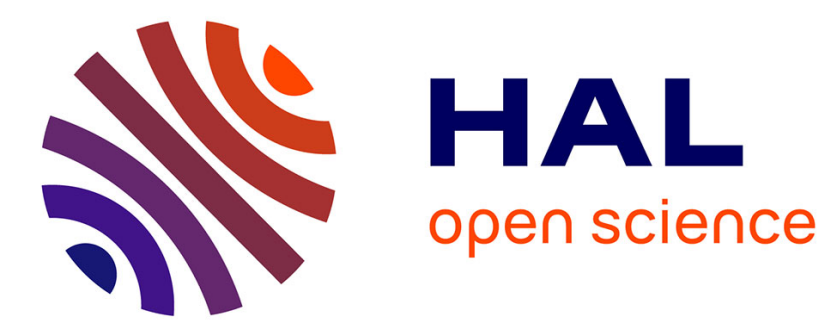

\title{
Are intelligent manufacturing systems sustainable?
}

André Thomas, Damien Trentesaux

\section{To cite this version:}

André Thomas, Damien Trentesaux. Are intelligent manufacturing systems sustainable?. 3rd Workshop on Service Orientation in Holonic and Multi-Agent Manufacturing and Robotics, SOHOMA 2013, Jun 2013, Valenciennes, France. pp.105-114. hal-00837905

\section{HAL Id: hal-00837905 https://hal.science/hal-00837905}

Submitted on 28 Jun 2013

HAL is a multi-disciplinary open access archive for the deposit and dissemination of scientific research documents, whether they are published or not. The documents may come from teaching and research institutions in France or abroad, or from public or private research centers.
L'archive ouverte pluridisciplinaire $\mathbf{H A L}$, est destinée au dépôt et à la diffusion de documents scientifiques de niveau recherche, publiés ou non, émanant des établissements d'enseignement et de recherche français ou étrangers, des laboratoires publics ou privés. 


\title{
Are Intelligent Manufacturing Systems Sustainable?
}

\author{
André Thomas ${ }^{1}$, Damien Trentesaux ${ }^{2}$ \\ ${ }^{1}$ Research Centre for Automatic Control (CRAN), CNRS (UMR 7029), Nancy University, \\ ENSTIB, 27 rue Philippe Seguin, 88000 Epinal, France \\ Andre.Thomas@cran.uhp-nancy.fr \\ ${ }^{2}$ Université Lille Nord de France, UVHC, Tempo-Lab., F-59313 Valenciennes France \\ Damien.Trentesaux@univ-valenciennes.fr
}

\begin{abstract}
This paper introduces and opens the debate on the place of "productdriven control" and, on a broader level, Intelligent Manufacturing and Services Systems in sustainable development and circular economy. First, IMS concept and perspectives on future industrial and economic systems, as well as their expected advantages and the challenges to be addressed are introduced. Different sustainability interpretations are then described. Third, our vision on possible impacts of IMS on a sustainable world is presented. This paper concludes with a set of challenging prospects.
\end{abstract}

Keywords: intelligent manufacturing systems, product-driven control, holonic control, intelligent product, sustainable development, sustainable manufacturing, $\mathrm{C} 2 \mathrm{C}$.

\section{Introduction}

On the one hand, in today's world, we are invaded by a huge of smart appliances: smart-phones, smart homes, smart-cars and so on... More and more intelligence is given to physical objects. Internet of Things (IoT), Ubiquitous or Pervasive Computing are common terms. The industrial and services domains are also impacted. Computer Integrated Manufacturing has evolved from classical top-down approaches to more bottom-up approaches where intelligence is distributed on products and resources (supply Chains and production systems), leading to Intelligent Manufacturing or Services Systems.

On the other hand, the international community is increasingly sensitive and aspires to more and more sustainability all over the world. Concepts such as sustainable development, circular economy, industrial ecology, sustainable manufacturing and so on, are becoming ever more popular and it seems to be necessary and urgent to implement them in today's economic activities.

Thus, the aim of this article is to open the debate on the place of "product-driven control" and, on a broader level, Intelligent Manufacturing Systems (IMS) including ser-

adfa, p. 1, 2011.

(C) Springer-Verlag Berlin Heidelberg 2011 
vices, in sustainable development and circular economy. A short state of the art on IMS systems will be proposed and the interpretations of sustainable approaches will be described. Finally, some challenging prospects will be proposed according to critical sustainable development indicators.

\section{Towards an ubiquitous world and Intelligent Manufacturing}

New opportunities arise with the deployment of concepts such as Internet of Things (IoT), Ubiquitous or Pervasive Computing. Through these concepts, objects of the real world are linked with the virtual world, thus enabling anytime, anyplace connectivity for anything and not only for anyone. Such concepts refer to a world where physical thinks or even people, as well as virtual environments, interact with each other (Sundmaeker, 2010), (Ley, 2007). A huge quantity of applications exist today, mobile phones, smart homes, smart cars, and a lot of applications exist in various sectors including services: medical sector (Bargagli, 1997), textiles sector (Schwarz, 2006), military applications (Park, 2002), home automation (Augusto, 2007), dismantling operations (Wong, 2002) or Transportation (Le Mortellec et al., 2013).

It seems to us, that production systems, supply chains, hospitals, and services in a broader sense, will be no exception to this evolution. The industrial, healthcare or services domains are today effectively also impacted. Initially, centralized approaches for such domains control and decision-making were used. These approaches were successful, mostly due to their ability to provide long-term and global optimization of production planning and scheduling, given a relatively stable operational context. In the 1990s, Production and Supply Chain Systems have changed from the traditional mass production to mass customization in order to deal with the increase of the global market competition.

As we highlighted in a previous article (Thomas et Al, 2012), industrial requirements have clearly evolved from the usual traditional performance criteria, described in terms of static optimality or near-optimality, towards new performance criteria, described in terms of reactivity, adaptability and visibility. A growing number of industrialists now want control systems that provide satisfactory, adaptable and robust solutions rather than optimal solutions that require the meeting of several hard assumptions (Trentesaux, 2009). Gradually the information technology improved, giving to the physical system entities (e.g., parts, resources) some decision-making capabilities and capacities in order to carry information. These improvements could be a new way to deal with the still unsolved problem concerning the de-synchronization of material and informational flows (Plossl, 1993). The concepts of Holonic Manufacturing Systems, Product-Driven Control Systems, Intelligent Products, Intelligent Manufacturing Systems, and Agent-Based Manufacturing, to name a few, have been proposed to design these future manufacturing systems. These concepts advocate that the products, and also, more globally, all the production resources, can be modelled as an association between two parts (i.e., a physical part and an informational part) to become a holon, interacting with human operators.

Recently, the French community of automatic control, at the request of the French institution, CNRS (Centre National de la Recherche Scientifique), has given its report 
on the "manufacturing of the future" (ARP FuturProd Report). The main objective of this research team was to highlight some strategic and tactic prospective and design a global vision of the products and services production systems for 2020/2030. The main key-words resulting are "innovation" and "sustainability". Behind them and at a more detailed point of view, it seems obvious that "distributed intelligence" will be implemented in a large variety of applications. The residual question will be then, how could they be in harmony with new sustainable development tendency?

\section{Sustainable development and related concepts}

«Eco-technic » concept is relative to all technics useful for environment preservation leading to the best usage of ecologic resilience capacity of "ecosystems". In that sense, an "ecosystem" is a balanced, stable and complex life system. There is an optimal use of material, each type of waste is reused by another organisms and energy needs will be met from renewable sources, solar energy for example.

The most frequently quoted definition of "Sustainable development" is from Our Common Future, also known as the Brundtland Report (WCED,1987):

"Sustainable development is development that meets the needs of the present without compromising the ability of future generations to meet their own needs. It contains within it two key concepts:

- the concept of needs, in particular the essential needs of the world's poor, to which overriding priority should be given; and

- the idea of limitations imposed by the state of technology and social organization on the environment's ability to meet present and future needs."

To meet these targets, political will have to be implemented with a viable and a global approach which is socially, environmentally and economically structured, leading to propose three pillars of sustainability (Figure 1) suggesting that both economy and society are constrained by environmental limits.

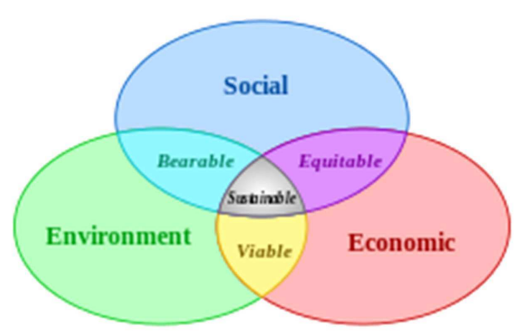

Figure 1: three pillars of sustainable development (SD) 
The main aim of circular economy is to optimize energy and materials flows at the system level, which could be a plant, an activity area, a country, etc... To limit energy consumption and wastes, the idea is to have a quasi-cyclic functioning such as in ecosystems.

In such interpretation, the system is constituted of two metabolisms. Figure 2, proposed by Ellen Mc Arthur foundation, gives an example of such a system:

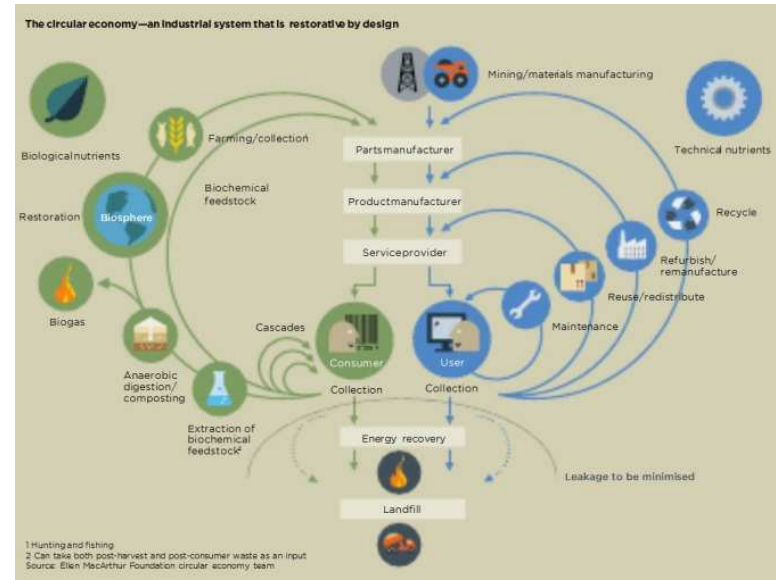

Figure 2: the two metabolisms of circular economy

The biological/organic metabolism : biosphere

An organic nutrient is a material designed to re-enter the organic cycle. The idea is to design products with such materials which can be discarded on the ground and go into a safe biodegradable process. Wood is a perfectly typically example.

The technical metabolism : technosphere

A technical nutrient is a material designed to re-enter the technical/industrial cycle from which it came. For example, some components of a television set could be interesting materials/components useful for others usages.

So, to control such systems according to the three pillars of sustainable development, the indicators system (Figure 3) leads to follow initiated actions and help to orientation determination. The famous "Cradle to Cradle" book describes some implementations of such a circular economy and proposes to develop indicators and relevant accreditations such as the $\mathrm{C} 2 \mathrm{C}$. 


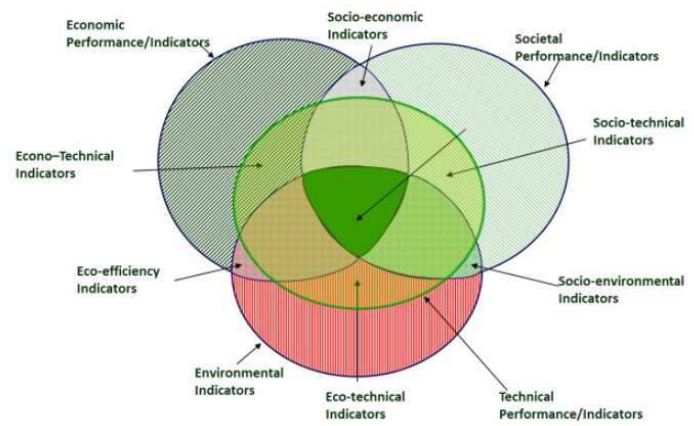

Figure 3 : Economic, ecological, social and technical dimensions of a sustainable product/process system

15 high level indicators have been associated to the 9 challenges of the French "Stratégie Nationale de Développement Durable" (SNDD) 2010-2013. Four of them are related to the economic and social contexts. All of them are completed by about thirty detailed indicators.

According to challenges, perspectives, and opportunities relative to IMS, it could be interesting to highlight the following indicators:

Context/national indicators :

Challenge 1 : Sustainable consumption and production (excerpts)

Material productivity

Production wastes evolution

Industrial efficiency

Employment

Challenge 4 : Climate change and energy

Total emissions of greenhouse gases

Carbon footprint

Challenge 5 : Sustainable transports/mobility

Transport energy consumption

Challenge 7 : Public health and risk management

Life expectancy

Occupational accident

The main objective of this article is to highlight how could IMS be compatible with sustainable development. Consequently, the questions are: how these indicators could be met in the context of IMS or how IMS can help to improve the level of these indicators. 


\section{Challenges for IMS in a sustainable world}

Recognizing that cyclical functioning leads to natural eco-systems durability, the concept of sustainable manufacturing was proposed (Ehrenfeld, 2004). One of the most recent definitions of sustainable manufacturing is given by Garetti and Taisch (2012) as "the ability to smartly use natural resources for manufacturing, by creating products and solutions that, thanks to new technology, regulatory measures and coherent social behaviors, are able to satisfy economic, environmental and social objectives, thus preserving the environment, while continuing to improve the quality of human life".

Consequently, in « industrial ecology » :

- « ecology » is relative to scientific ecology which is eco-systems study.

- “industrial” concerns today's industrial society (production, distribution systems, public services and so on...)

By seeking to copy rules and principles of the nature, sustainable manufacturing could also have as scientific approaches, such as biomimetic ones. Some research works already exist in this domain concerning stigmergy, viable systems (Herrera, 2011) and so on ...

From the previously introduced definition of sustainable manufacturing, it is interesting to note the use of the adjective "smartly", which enables us to link the "IMS" concept to the "sustainable manufacturing" concept in the sense that IMS can be seen as a way to "smartly use natural resources" in conjunction with the challenge 1 previously introduced ("Sustainable consumption and production, topic: Industrial efficiency"). For example, opportunistic energy management at the shop floor level may be naturally addressed using smart intelligent distributed devices. A typical illustration of this approach is proposed by (Karnouskos et al., 2009). The authors studied the integration of an energy monitoring function in the entities of a manufacturing system (e.g., programmable logic controller, enterprise resource planning, embedded devices.). According to their models, the future resources are expected to auto-manage their energy consumption. These resources will switch into a low energy consumption state if currently no task is executed on them.

In this context, the key point that militates to the use of more "bottom-up" and more intelligent approaches rather than classical top-down approaches in related to the fact that in job-shop and flow-shop problems, the scheduling problem without any attention paid to energy is known to already be NP-Hard. As a consequence, the resolution time of centralized methods is very long. Adding another constraint (e.g., energy consumption) or adding another objective in the objective function (e.g., minimize the energy) will make the resolution even more difficult. This could make such methods unable to react to uncertainty (e.g., changes or perturbations in a short time, dynamic energy pricing in the smart grid, etc.), and scarcely compatible with the reactivity required in a dynamic context. 
But the "intelligent systems" approach can also be concerned indirectly, at a more global level, beyond the classical scope of the manufacturing phase, by proposing solutions to increase links among the different phases of products and resource life cycles, including better traceability, quality management and contributing to the optimization of recycling. Indeed, embedding or distributing intelligence among products and resources enables to provide information closer to the physical parts of products and systems, even to attach this information to these systems, reducing decisional loops and increasing information accuracy. For example, if a smart system is able to memorize the way it has been used and the history of its parts replacement, this information can be useful for maintenance or dismantling and recycling issues (Sallez et al., 2010).

According to the indicators previously introduced, we can illustrate some interests and contributions of IMS thanks to the following frameworks:

\begin{tabular}{|c|c|c|c|c|c|c|c|c|c|c|}
\hline & \multicolumn{10}{|c|}{ Sustainable development indicators (extracts) } \\
\hline & \multicolumn{4}{|c|}{ Challenge $1=$ Sustainable consumption and production } & \multicolumn{3}{|c|}{$\begin{array}{c}\begin{array}{c}\text { Challenge } 4=\text { Climate change and } \\
\text { energy }\end{array}\end{array}$} & \multicolumn{2}{|c|}{$\begin{array}{c}\text { Challenge } 5=\text { Sustainable } \\
\text { transports } / \text { mobility }\end{array}$} & \multirow{2}{*}{\begin{tabular}{|c}
$\begin{array}{c}\text { Challenge } 7= \\
\text { Public health and } \\
\text { risk management }\end{array}$ \\
Life expectancy
\end{tabular}} \\
\hline & $\begin{array}{c}\text { Material } \\
\text { productivity }\end{array}$ & $\begin{array}{l}\text { Production wastes } \\
\text { evolution }\end{array}$ & Employment & $\begin{array}{l}\text { Industrial } \\
\text { efficiency }\end{array}$ & \begin{tabular}{|c|}
$\begin{array}{c}\text { Total } \\
\text { emissions } \\
\text { of } \\
\text { greenhouse } \\
\text { gases }\end{array}$ \\
\end{tabular} & $\begin{array}{c}\text { Carbon } \\
\text { footprint }\end{array}$ & $\begin{array}{c}\text { Energy } \\
\text { consumption }\end{array}$ & $\begin{array}{l}\text { Transport energy } \\
\text { consumption }\end{array}$ & $\begin{array}{c}\text { Emissions } \\
\text { of } \\
\text { greenhouse } \\
\text { gases }\end{array}$ & \\
\hline Stra & & & \multirow{3}{*}{\begin{tabular}{|l|} 
Activities p \\
\\
Resources \\
optiization
\end{tabular}} & erpetu- & & & (Short)s & & & \\
\hline Tactic & $\begin{array}{c}\text { Inventory and } \\
\text { cash expenses } \\
\text { minimisation }\end{array}$ & $\begin{array}{c}\text { Inventory management } \\
\text { and traceability }\end{array}$ & & $\begin{array}{c}\text { Inventory } \\
\text { management } \\
\text { and } \\
\text { traceability }\end{array}$ & \multicolumn{5}{|c|}{$\begin{array}{l}\text { Resources and ve hicle routings optimisation - lead-times and inventory } \\
\text { minimization }\end{array}$} & $\begin{array}{c}\text { Inventory } \\
\text { management and } \\
\text { traceability in } \\
\text { hospitals }\end{array}$ \\
\hline Operationnal & \begin{tabular}{|c|} 
Material yield \\
"on-line" \\
optimization
\end{tabular} & Physical flows control & & $\begin{array}{c}\text { Physical } \\
\text { flows control }\end{array}$ & \multicolumn{5}{|c|}{ Energy and short distance road transport flows optimization and control } & $\begin{array}{c}\text { Drugs } \\
\text { dispensation } \\
\end{array}$ \\
\hline
\end{tabular}

This first framework highlights some chosen challenges according to decision-making and industrial/structural levels.

\begin{tabular}{|c|c|c|c|c|c|c|c|c|c|c|}
\hline & \multicolumn{10}{|c|}{ Sustainable development indicators (extracts) } \\
\hline & \multicolumn{4}{|c|}{ Challenge $1=$ Sustainable consumption and production } & \multicolumn{3}{|c|}{$\begin{array}{l}\text { Challenge } 4=\text { = Climate change and } \\
\text { energy }\end{array}$} & \multicolumn{2}{|c|}{$\begin{array}{l}\text { Challenge } 5=\text { Sustainable } \\
\text { transports/mobility }\end{array}$} & \multirow{2}{*}{ 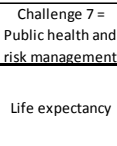 } \\
\hline & $\begin{array}{c}\text { Material } \\
\text { productivity }\end{array}$ & $\begin{array}{l}\text { Production wastes } \\
\text { evolution }\end{array}$ & Employment & $\begin{array}{l}\text { Industrial } \\
\text { efficiency }\end{array}$ & \begin{tabular}{|c|} 
Total \\
emissions \\
of \\
greenhouse
\end{tabular} & $\begin{array}{c}\text { Carbon } \\
\text { footprint }\end{array}$ & $\begin{array}{c}\text { Energy } \\
\text { consumption }\end{array}$ & $\begin{array}{l}\text { Transport energy } \\
\text { consumption }\end{array}$ & \begin{tabular}{|c|}
$\begin{array}{c}\text { Emissions } \\
\text { of } \\
\text { greenhouse } \\
\text { gases }\end{array}$ \\
\end{tabular} & \\
\hline Context & $\begin{array}{c}\text { Consumption } \\
\text { and material } \\
\text { wastes } \\
\text { minimization }\end{array}$ & Co-products usages & $\begin{array}{c}\text { Local } \\
\text { employment }\end{array}$ & $\begin{array}{c}\begin{array}{c}\text { Low prices } \\
\text { for } \\
\text { economical } \\
\text { sustainability }\end{array} \\
\end{array}$ & \multicolumn{3}{|c|}{ Sustainable Suppy Chains design } & \multicolumn{2}{|c|}{ Short distance roads } & Hospital \\
\hline Concept & $\begin{array}{c}\text { Defects, } \\
\text { products real } \\
\text { time vision }\end{array}$ & $\begin{array}{l}\text { Co-products need } \\
\text { global knowledge }\end{array}$ & $\begin{array}{c}\text { Employment } \\
\text { robustness }\end{array}$ & $\begin{array}{c}\text { Decision } \\
\text { making at } \\
\text { various levels }\end{array}$ & \multicolumn{5}{|c|}{ Routings and material resources usage minimization } & $\begin{array}{l}\text { Quality of service } \\
\text { and disponibility }\end{array}$ \\
\hline Logical & \multicolumn{2}{|c|}{ Mono-multi criteria } & $\begin{array}{r}\begin{array}{r}\text { Management } \\
\text { rul }\end{array} \\
\end{array}$ & $\begin{array}{l}\text { and lot sizing } \\
\text { es }\end{array}$ & \multicolumn{3}{|c|}{$\begin{array}{c}\begin{array}{c}\text { Mono-multi criteria - Heterogeneous } \\
\text { models }\end{array} \\
\end{array}$} & \multicolumn{2}{|c|}{ Mono-multi criteria } & $\begin{array}{c}\text { Mono-multi } \\
\text { criteria }\end{array}$ \\
\hline Physical & \multicolumn{2}{|c|}{ Marking } & RFID, ba & & \multicolumn{3}{|c|}{ RFID, GPS, WSN } & \multicolumn{2}{|c|}{ RFID, GPS } & RFID, Barcodes \\
\hline Detail & $\begin{array}{l}\text { knapsack } \\
\text { algorithms }\end{array}$ & & & $\begin{array}{c}\text { Optimization, } \\
\text { simulation }\end{array}$ & & & & \multicolumn{2}{|c|}{ PL, PLNE, ... } & \\
\hline
\end{tabular}

This second framework highlights the same challenges according to system abstraction levels.

Unquestionably, IMS technologies, architectures, management and control approaches will be useful for sustainable industries. Already, and especially at a production activity control level, a lot of successful experiences exist (Pannequin, 2009), but in a restrictive SD sense. Indeed, the classical researches concerning IMS applications on shop-floors and supply chains and leading to more industrial efficiency are relevant. But, they address only one pillar of the SD (the economic one) and note that, in this 
domain, the performance is measured according the lowest level of the 3 pillars (economic, environmental and societal pillars, see fig. 3) ! Finally, we have observed that very few works in the IMS community concern effectively the SD in industry with a will to balance the attention paid to the three pillars. Some production management research communities, such as in the IFIP, pay attention to SD but still with few considerations paid to link this with IMS approaches. On the other side, IEEE and IFAC production management communities pay a lot of attention to IMS approaches but with few attention paid to link this with SD. Maybe the time has come to merge these sensibilities. Typically, the concept of PSS (Product -Service System) could be the missing link in the studied context.

It seems obvious that real time identification, tracking or tracing could improve efficiency and control of the systems, but some interests could be also highlighted at higher levels (strategic and tactic) which concern supply chains design or industrial systems specification, leading to shorter routings in transport area, to more economic robustness and so on. On the other hand, at a conceptual point of view and thanks to the IMS capacity to provide a global knowledge of the system state, some others targets could be addressed, as economic or quality of service robustness.

\section{Conclusion}

In this article, we had as objective to open the debate on the place of Intelligent Manufacturing and Services Systems, in sustainable development and circular economy. We have discussed about IMS and the interpretations of sustainable approaches in that context. Finally, we proposed a framework describing the place of some challenging prospects according to critical sustainable development indicators.

Again and unquestionably, we are sure that IMS technologies, architectures, management and control approaches will be useful, in our foreseeable future, for sustainable industries. Thereby, the proposed frameworks could be a first tentative to highlight some beacons of innovation and to structure next research works and we would propose a more detailed analysis shortly.

\section{References}

Sundmaeker, H., Guillemin, P., Friess, P. and Woelfflé, S. (2010), 'Vision and challenges for realising the Internet of Things', Cluster of European Research Projects on the Internet of Things, European Commision .

D. Ley, Becta, Ubiquitous Computing", emerging technologie 2 (2007) 64-79.

R. Bargagli, D. Wynn-Williams, F. Bersan, P. Cavacini, S. Ertz, F. Frati, D. Freckman, R. LewisSmith, N. Russell, A. Smith, Field report, Biotex 1: first BIOTAS expedition, Newsletter of the Italian Biological Research in Antarctica 1 (1995-96) (1997) 42-58.

A. Schwarz, L. Van Langenhove, Report on State-of-the-art on intelligent textiles, "Development of a strategic Master plan for the transformation of the traditional textile and clothing into a knowledge driven industrial sector by 2015", Tech. Rep., Clevertex, 2006.

S. Park, K. Mackenzie, S. Jayaraman, The wearable motherboard: a framework for personalized mobile information processing (PMIP), in: 39th Annual

J. Augusto, Ambient Intelligence: The confluence of ubiquitous/ pervasive computing and artificial intelligence, Intelligent Computing Everywhere (2007) 213-234. 
C. Y. Wong, D. Mcfarlane, A. A. Zaharudin, V. Agarwal, The Intelligent Product Driven Supply Chain, in: International Conference on Systems, Man and Cybernetics, 4-6, 2002.H. Sundmaeker, P. Guillemin, P. Friess, S.Woelffl'e, Vision and challenges for realising the Internet of Things, Cluster of European Research Projects on the Internet of Things, European Commision .

Le mortellec A., Clarhaut J., Sallez Y., Berger T., Trentesaux D. (2013). Embedded Holonic Fault Diagnosis of Complex Transportation Systems. Engineering Applications of Artificial Intelligence, 26(1), pp. 227-240

Thomas A., Trentesaux D., Valckenaers P., Intelligent distributed production control, Journal of Intelligent Manufacturing, (2012-12-00)

Trentesaux D. (2009). Les systèmes de pilotage hétérarchiques: Innovations réelles ou modèles stériles? J. Européen des Systèmes Automatisés, 1165-1202.

Plossl W.G. , La nouvelle donne de la gestion de la production - Afnor gestion, Paris, 1993.

WCED - World Commission on Environment and Development. Our common future. Oxford: Oxford University Press, 1987 p. 43.

Garetti, M and Taisch, M. (2012), "Sustainable manufacturing: trends and research challenges", Production Planning and Control, 23 (2-3), February-March, pp. 83-104.

Ehrenfeld, John, 2004, Can Industrial Ecology be the Science of Sustainability?. Journal of Industrial Ecology, vol 8., editorial, pp 1-3 doi:10.1162/1088198041269364.

Herrera C; Belmokhtar S; Thomas A, Viable System Model approach for holonic product-driven manufacturing systems, First Worshop on Service Orientation in Holonic and Multi-Agent Manufacturing Control (SOHOMA 2011), 1st Workshop on Service Orientation in Holonic and Multi Agent Manufacturing Control, SOHOMA 2011, (2011-06-20)

S. Karnouskos, A. W. Colombo, J. L. M. Lastra, and C. Popescu, "Towards the energy efficient future factory," in Industrial Informatics. 7th IEEE Int Conf on, 2009, pp. 367-371.

Sallez Y., Berger T., Deneux D., Trentesaux D. (2010). The Life Cycle of Active and Intelligent Products: The Augmentation concept. International Journal of Computer Integrated Manufacturing, 23(10), pp. 905-924

Pannequin R; Morel G; Thomas A, The performance of product-driven manufacturing control: An emulation-based benchmarking study, Computers in Industry, (2009-00-00) 